Article

\title{
Polycentricity of the city's metropolitan system as a factor increasing security in times of danger - on the example of Cracow.
}

Rafał Blazy ${ }^{1}$, Anna Ziobro ${ }^{2}$

1 Faculty of Architecture, Cracow University of Technology, 24 Warszawska St. 31-155 Cracow, Poland;
rblazy@pk.edu.pl
2 Faculty of Architecture, Cracow University of Technology, 24 Warszawska St. 31-155 Cracow, Poland;
aziobro@pk.edu.pl

\begin{abstract}
Service polycentricism, in the face of the pandemic, took on a new significance because of sanitary requirements. Population concentrations in large service centres face a high risk of infection both at their destination and during the trip. Higher-tier services were largely closed during the threat's peak. In this paper, the focus of the study has been placed on the urban scale of a large city's polycentricism as seen through the prism of service concentrations, which, to a degree, are commuter destinations, but primarily act as attractors that are not associated with work - they satisfy higher-tier service needs. To formulate the investigative apparatus used to study the functiospatial structure of Cracow. The current threat, as well as the high probability of similar situations happening in the future, will probably lead to changes in behaviour patterns of consumers and service providers in reference to siting. Local service centres that are accessible to pedestrians, due to safety-related considerations, can gain significant popularity.
\end{abstract}

Keywords: urban security; functio-spatial structure, polycentricity, covid security

\section{Introduction}

Urban security is a subject that is discussed increasingly often. The geospatial modelling of urban security allows us to identify streets and areas of the city where its population concentrates. An increasing number of three-dimensional tools intended for multi-planar urban analysis are developed [e.g. 1-3]. For instance, data like population density or household income, when paired with the three-dimensional structure of the city and behavioural patterns, can allow scholars to assess resilience against possible dangerous events [4]. Academic research has associated the impact of spatial characteristics with crime rates in particularly densely developed areas, investigating them with the aim of improving the quality of the housing environment [5]. The new situation of the epidemic threat has laid bare the shortcomings of the functio-spatial structure of cities. The presently marginalised need for sanitary security has embedded itself profoundly in the social conscious and has gained a new dimension. Analysis of the concentration of residents and the ability to control these concentrations in the face of a sanitary threat is an important aspect of a society's security and safety. Particularly in large cities, the distribution of fundamental service concentrations should enable the separation of a part of the population and the enactment of mobility restrictions. This is associated with matters of polycentricism and service multi-centrality, as explained later in the paper. 
Polycentricism depends on scale-whether it is regional or urban, it is perceived differently. Its perception also changes over time (across decades or centuries). The functio-spatial structure of the city is dependent on current policy and on free-market phenomena and behavioural patterns (both global and local). In the paper, this discussion is conducted as based on observations of Cracow's demographic explosion, urbanisation and the following suburbanisation and change in its functio-spatial structure. This is an interesting case, as the city underwent a radical transformation from a relatively small city into an urban agglomeration over three decades after the Second World War, which disrupted its functio-spatial structure. In the current century, these structural dysfunctions have become more severe as the population continuously rises and the city extends its territory. Changes in mobility patterns have likewise had a pronounced effect. In the context of an inefficient mass transport system, the number of cars continues to rise. In spite of an increasingly rigorous transport policy, their number does not decrease and many factors indicate that the fear caused by the COVID-19 pandemic may reinforce the need to personally own a car. These phenomena have their structural consequences, which the author analyses in this paper.

\section{Object and Method of Research}

The research method used in this study was based on investigating the functio-spatial structure of Cracow for many years. In the years 2016-2017, the author took part in a research and development project entitled "Model of the spatial structure of Cracow. A Planning Perspective", carried out by the Cracow University of Technology and commissioned by the City of Cracow Spatial Planning Bureau. This research was based on multi-planar analyses of the spatial structure in combination with transport models and statistical data. Conclusions as to the maladjustment of effective public transport geometries relative to the belt-like layout of Cracow's housing estates were published by the author in [6]. In subsequent years, the author performed further studies of pedestrian accessibility to Cracow's service concentrations. These studies were conducted as a part of the TRL+ grant 1 by the Cracow University of Technology and co-funded by the ministry with the aim to define contemporary urban planning standards. This paper presents the findings of these studies and observations of the functioning of Cracow during the COVID-19 pandemic between March and May 2020. The study focused on the city of Cracow, within the context of the Cracow agglomeration.

\section{Cracow's functio-spatial structure}

Cracow is the second-largest city in Poland. It is an interesting research case due to the radical transformations of its functio-spatial structure and dynamic demographic changes that took place in the previous century. The city, founded in the Middle Ages based on the Magdeburg rights, was given a grid-like plan. Later, up to the Second World War, it developed as a monocentric, radio-circular layout-in 1941, the city's limits were extended, increasing its radius from around $4.5 \mathrm{~km}$ to $7.5 \mathrm{~km}$, but it still remained a concentric layout (fig. 1). Immediately after the war, the communist government decided to build a new metallurgy planned named after Lenin near Cracow. A new city for the plant's workers was built between said plant and Cracow and was named Nowa Huta. Its territory was incorporated into Cracow just a few years later, disrupting the concentric spatial structure-the city's eastern border was relocated by around $10 \mathrm{~km}$ (fig. 1). A bipole was formed, home to a fourth of Cracow's population, together with a metallurgy plant that employed 40 thousand people in the 1970 s.

1 The goal of the TRL+ competition is to support the process of commercialising research and development outcomes. The project is aimed at promoting academic achievement, increase its impact on the development of innovation and support cooperation between the academic community and the economic environment. 


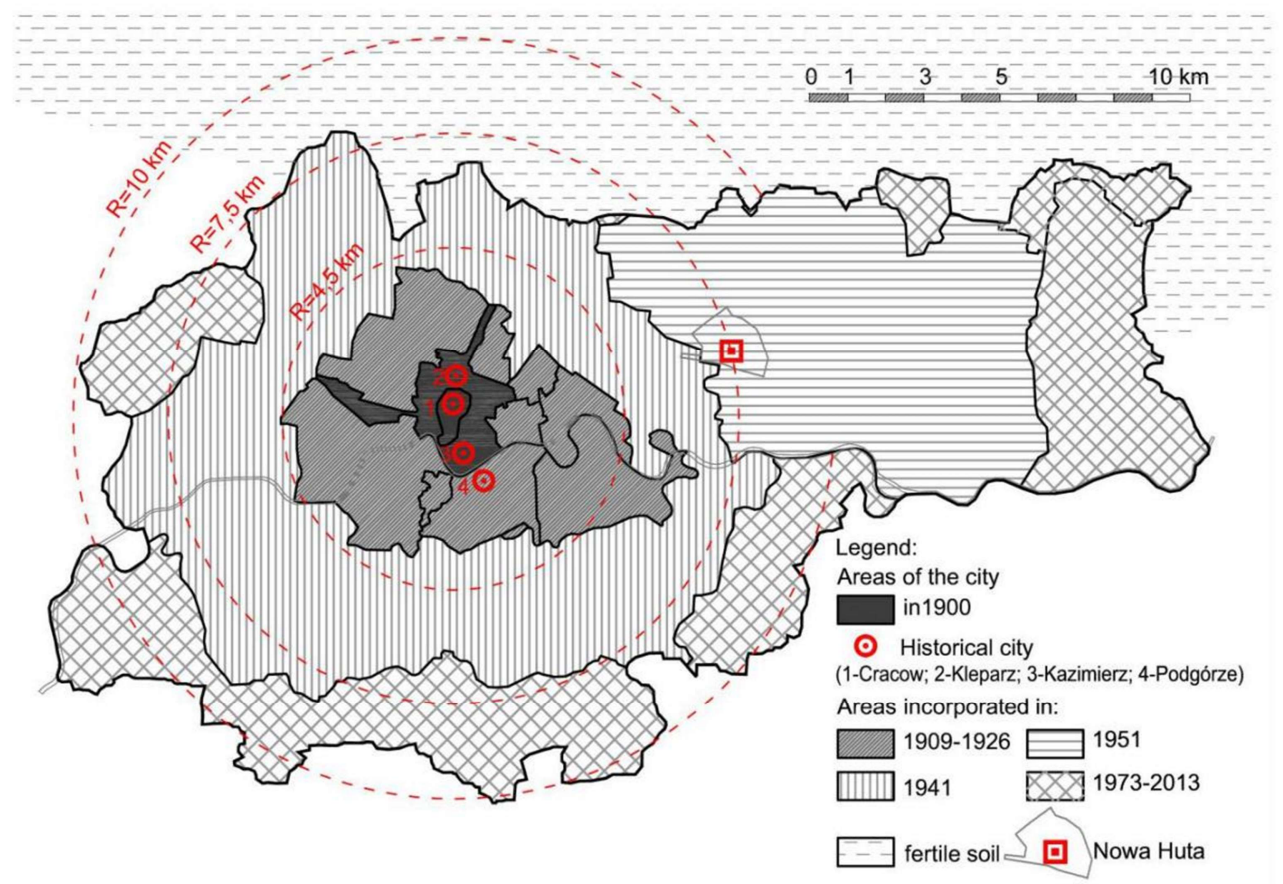

Figure 1. Spatial development of Cracow, A. Ziobro

This was a groundbreaking moment in the city's development. In the middle of the century, Cracow had a population of around 300 thousand, which was mainly employed in the service sector. Introducing industry on such a large scale resulted in a workforce influx and the necessity to build housing for workers. This quickly became a priority due to their rising numbers. Infrastructural projects, particularly high-tier service functions, could not keep up. Numerous housing estate service concentrations were built during this period. They continue to perform well to this day, satisfying the basic needs of nearby residents.

Over the course of a single generation (around 26 years), the city's population doubled, reaching 600 thousand, and the city itself turned into an agglomeration. New housing estates were planned as a part of a belt-like, parallel layout. For the next several decades, Cracow's planners tried to balance the city's distorted functio-spatial layout, in which a belt-like layout of housing estates was superimposed upon a radio-circular model. The eastern industrial and housing bipole (Nowa Huta - fig. 1) still suffers from a service deficit. Despite a functionally bi-focal spatial structure, the city was still monocentric. Further planning documents featured different locations for a new subcentre between the historical centre and Nowa Huta. However, attempts to establish it were not successful due to the crisis of the 1980s and the change of Poland's economic and political system.

Post-war changes in administrative borders were based on incorporating land located to the east, the south and the west into the city. Areas to the north provided food for the urban agglomeration due to their fertile land, suitable for the growth of wheat, which is why they were not incorporated into the city. After the political transformation of 1989, these areas were gradually built up. As in the case of other countries with a similar history, the fall of communism initiated urban sprawl due to a lack of proper policies and governance systems [7-11]. Along with the beginning of the twenty-first century, suburbanisation considerably intensified, while the northern areas, previously protected from urbanisation, became profitable for real estate developers due to their proximity to the city centre. A wide range of services, including a cultural offer, attracts [12] new residents to the city and its suburbs. 
The policy of nearby municipalities is conducive to urban sprawl, as it runs counter to that of Cracow's administration. The agglomeration is not planned in a coordinated way. Each municipality implements local policies aimed at the benefit of its residents, who want to profit from the sale of expensive buildable land. Meanwhile, the city of Cracow faces all of the consequences of an unplanned extension of its urban structure. Every year, additional constraints that affect car users are implemented. Paid parking zones in the centre are successively extended and are accompanied by parking fee hikes. A network of one-way streets has been established in the city centre, which requires drivers to meander through them for extended periods of time to get to their destination, while entire zones have traffic restrictions in place. At the same time, public transport does not provide an attractive alternative due to considerable delays (caused by traffic congestion), packed trams and buses in the centre and infrequent bus schedules for lines destined for the city's outskirts and peripheries. The combined length of bus lanes in 2018 was only $28.6 \mathrm{~km}$, while that of bicycle paths was $213.7 \mathrm{~km}$. When compared with Copenhagen, which has a similar number of residents, the length of bicycle paths is around $400 \mathrm{~km}$, while public transport in the city - which is based on urban and underground rail, which Cracow does not have-operates very efficiently.

\section{Transport policy in Cracow and social mobility}

In October 2017, the municipal administration commissioned a study of the number of vehicles entering the city. This study found that 246 thousand vehicles enter Cracow every day. Most of these vehicles, around 150 thousand, entered the city from the north. Only 40 thousand vehicles used the city as a transit route. The city's road infrastructure is insufficient and cannot accommodate this amount of traffic.

In Cracow proper there are 493 thousand registered vehicles (table 1).

Tab. 1.Passenger cars in Cracow, Cracow County and Wieliczka County, source: General Statistics Office in Poland, online access: 24.02.2020

\begin{tabular}{|c|c|c|}
\hline & 2002 & 2018 \\
\hline \multicolumn{3}{|l|}{ Cracow } \\
\hline - population & 757547 & 771069 \\
\hline - number of cars & 257823 & 493021 \\
\hline - passenger cars/1000 residents & 340 & 639 \\
\hline \multicolumn{3}{|l|}{ Cracow County } \\
\hline - population & 239344 & 277145 \\
\hline - number of cars & 88343 & 178958 \\
\hline - passenger cars/1000 residents & 369 & 646 \\
\hline \multicolumn{3}{|l|}{ Wieliczka County } \\
\hline - population & 102636 & 127078 \\
\hline - number of cars & 38634 & 79160 \\
\hline - passenger cars/1000 residents & 376 & 623 \\
\hline \multicolumn{3}{|c|}{ Cracow County, Wieliczka County and Cracow combined } \\
\hline - population & 1099527 & 1175292 \\
\hline - number of cars & 384800 & 751139 \\
\hline - passenger cars $/ 1000$ residents & 350 & 639 \\
\hline
\end{tabular}

When one adds the 206 thousand vehicles that drive around the city and use its parking facilities, this number increases to 699 thousand. The city, whose population is 771 thousand, faces the problem of around 740 thousand cars driving around it every day. 
Rising prosperity and affluence contribute to greater social mobility and owning a passenger car is an increasingly common choice. Motivated by comfort, more and more people began to satisfy non-basic needs in easily accessible places outside of the city centre that are equipped with parking spaces. Free-market mechanisms, combined with client preferences (access by car) have resulted in the formation of service concentrations that have grown to the rank of subcentres over the past decade (fig. 2).

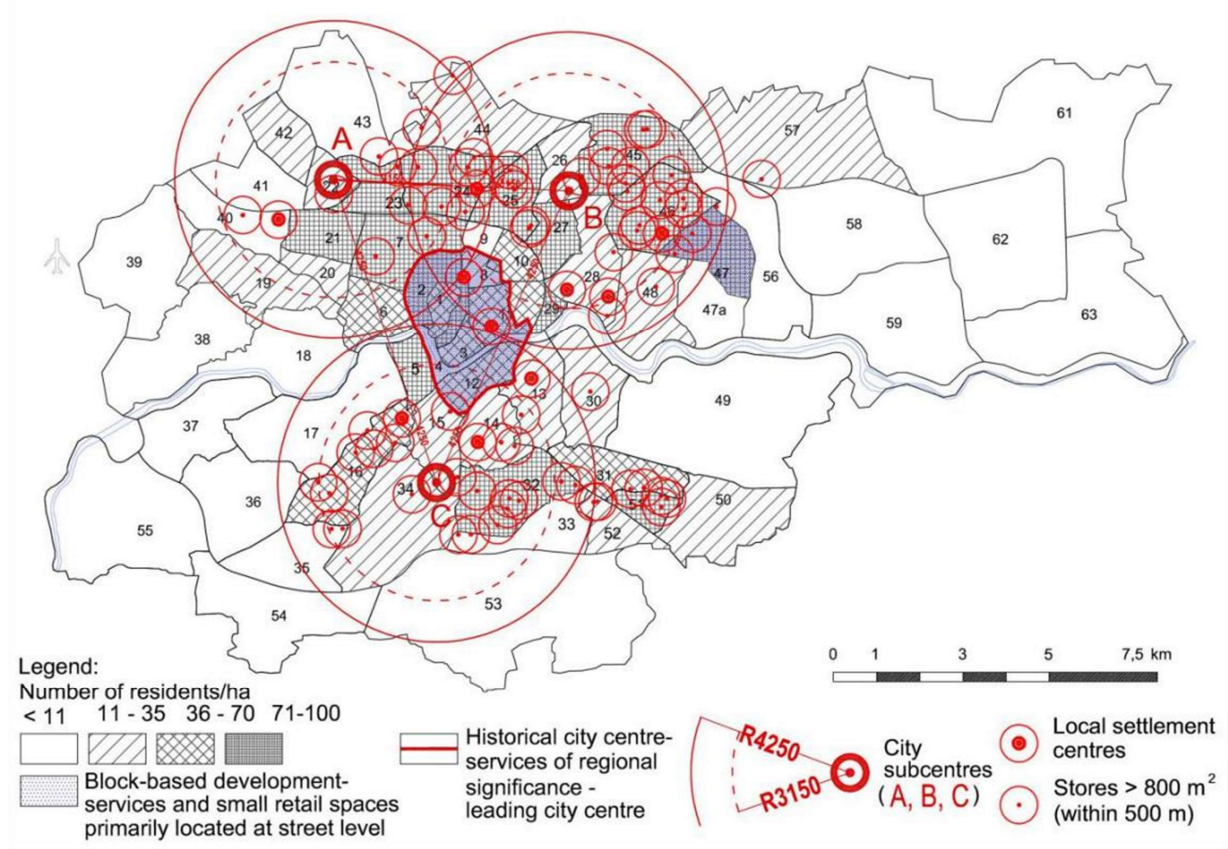

Figure 2. Freestanding commercial buildings with a floor area greater than $800 \mathrm{~m} 2$, A. Ziobro 2018

During the study of the changes that take place in Cracow, the author referenced data provided by the General Statistics Office in Poland, which had been collected for counties. Upon comparing available data for 2002 with the most recent information (for 2018), it was observed that, over a period of 17 years, the population of Cracow and its neighbouring counties (fig. 3) increased by $2 \%$ and $7 \%$, respectively. During this time, the level of motorisation increased almost twofold-in Cracow it increased from 340 to 639 vehicles per 1000 residents, while in the Cracow functional area it increased from 350 to 639 as well. The number of passenger cars in Cracow proper increased by over 235 thousand. In Cracow's general vicinity and its adjoining counties, it increased by over 366 thousand (table 1). The consequences of this are visible every day in the form of severe traffic congestion. The increasingly restrictive transport policy of the city, which restricts traffic in the city centre, is becoming more and more inconvenient to the residents of the urban functional zone. At the same time, public transport is not adapted to the needs of residents and does not constitute a reasonable alternative. The increase in the centre's capacity is conditioned by the ability to access it by car [13]. It should also be noted that, the principle of least resistance, i.e. reaching one's goal using the shortest path available, became a foundation for August Lösch's theory from 1940 [14], which explains the significance of the circulatory accessibility of urban centres. Due to the worsening of the main city centre's accessibility, three service concentrations located along Cracow's main roads were observed to rise to the rank of subcentres (fig. 2). The southern site is accessible by rail (via extant tram connections and an urban rail stop that is under construction); the remaining two sites are accessible solely by car, which is problematic. 


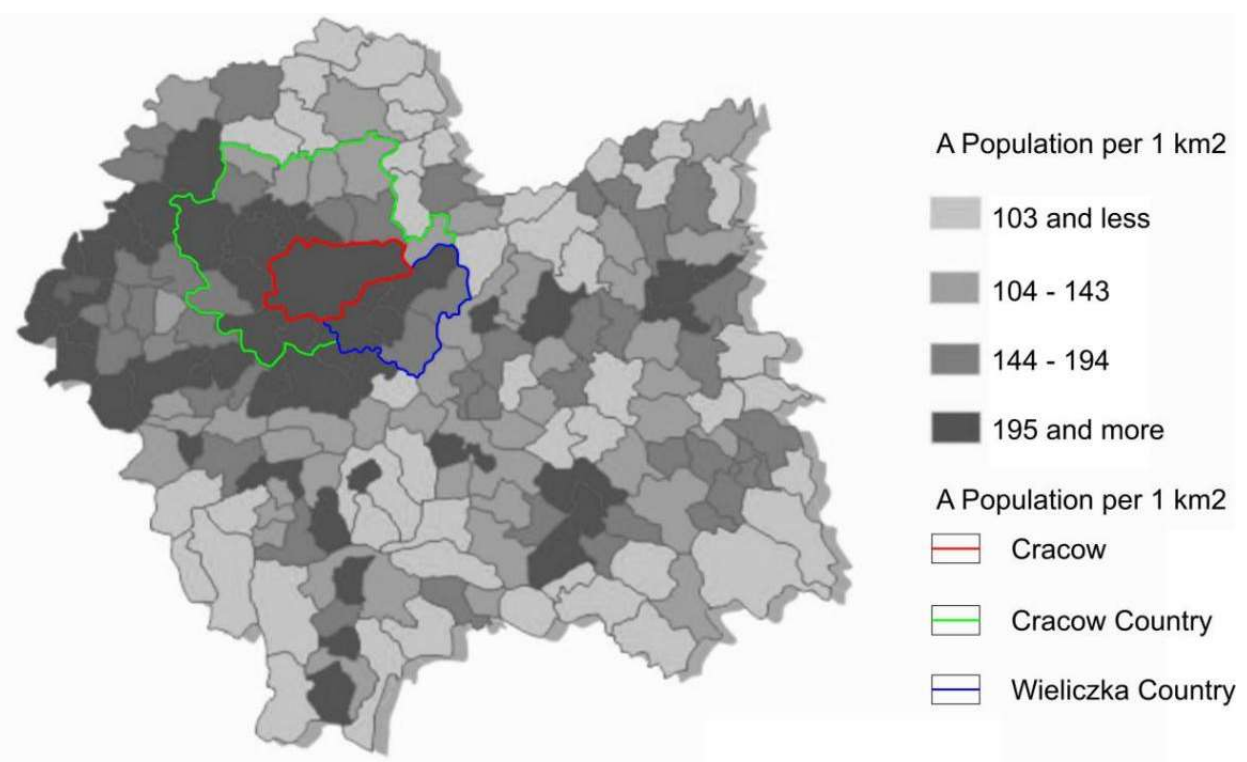

Figure 3. A population density of the Malopolska Region in 2010, based on statistical data (krakow.stat.gov.pl)

\section{The scale of polycentricism and its changes over time}

Depending on the scale at which we look at a given settlement layout, it can be interpreted either in a monocentric or polycentric manner [14-17], An internally polycentric agglomeration composed of a single core city will be seen as a monocentric layout from a regional perspective-as opposed to a polycentric conurbation. The perception of polycentricism can also change over time and a given city's spatiofunctional development.

At the turn of the nineteenth century, the following towns were incorporated into Cracow: Kleparz (1792) and Kazimierz (1800). The Free Royal Town of Podgórze was incorporated just over a century later (1915). The layout of four previously independent towns was perceived in a clearly polycentric manner. Looking back, in the context of the many later phases of the city's development, the functio-spatial structure that formed up to the middle of the twentieth century is perceived to be monocentric, radio-circular (with a radius of around $7.5 \mathrm{~km}-$ fig. 1). A radical change took place only with the construction of Nowa Huta and its incorporation into Cracow in 1951. The structure became deformed, but did a second centre emerge?

The author, referencing the Polish meaning of the word centre, points to three levels of its understanding that are dependent on the scale on which it is applied: the global level, the urban planning level (a functional and geometric outlook) and the architectural level.

On the global scale, the centre is an important node within a settlement network (a megacity, a metropolis, an agglomeration), which must account for both physical relationships and information-related linkages and its role within virtual space.

On the urban planning scale, we encounter two meanings of the word "centre":

-the geometric meaning, which refers to the middle portion of a settlement layout, which is a natural site for services regardless of rank or reach,

-the functional meaning, where standards and theories concerning central places [18] and hierarchical models [19] apply, in addition to polycentric and network-based models [20-22].

On the architectural scale, the notion of the centre typically refers to a building or area and highlights an interesting offering, a broad range of services, such as an arts centre, a sports centre or a dentistry centre.

The scale of perception becomes particularly significant to urban planners due to growing mobility and the complexity of spatial and social linkages [23]. 
Most publications on polycentric structures pertain to the regional scale, with the main indicators of polycentricism understood as such being commuting to one's place of employment. The Standard Metropolitan Area (SMA), which identifies metropolitan areas based on commuting trips, was formulated in 1949 [24]. Afterwards, numerous publications concerning the delimitation of monocentric and polycentric metropolitan areas were written around the world during the 1970s. In Poland, the subject of delimiting agglomerations and later metropolises was discussed at length [25-29]. Metropolitan areas are characterised by decentralised employment patterns [30].

On the urban planning scale, the internal, functional polycentricism of cities is also largely studied via investigating the flow of commuters [e.g. 31, 32]. Some publications and studies also highlight a different view of non-work polycentrism $[33,34]$. The flow of the traffic of society is also of considerable significance in the context of safety from epidemics. Large concentrations of people and traffic in large cities are conducive to the rapid spread of viruses [35-37]. In this context, the security of the city's functio-spatial structure will depend on the spatial distribution of urban centres and centres and how these units will interact [38].

In this paper, the focus of the study has been placed on the urban scale of a large city's polycentricism as seen through the prism of service concentrations, which, to a degree, are commuter destinations, but primarily act as attractors that are not associated with work - they satisfy higher-tier service needs. To formulate the investigative apparatus used to study the functio-spatial structure of Cracow, the author analysed Polish literature and Polish urban planning standards [39, 40]. In the author's opinion, these studies and W. Christaller's theory [11] indicate that the centre constitutes the highest level of service concentration. The two lowest tiers are local (intended to satisfy everyday needs of residents) and supra-local service centres (which are frequently accessed). The subsequent, higher tiers pertain to centres-they are specialised locations that satisfy sporadic needs (e.g. district, regional or state-level needs). Such centres are typically formed by sites that play the role of at least district centres of large cities that provide services to no less than 100 thousand people and the centres of large cities, e.g. voivodeship or provincial capitals. Polycentricism demonstrated on this scale also refers to the internal functio-spatial structure of a megacity/metropolis/agglomeration and can account for the role of concentration in virtual space.

\section{City polycentricism during a pandemic}

The previously mentioned urban planning standard, which was used during the period of the greatest wave of building panel-block housing estates in Poland, defined the principles of planning structural housing units and equipping them with basic and higher-tier services (to be located at a distance of $500 \mathrm{~m}$ and $800 \mathrm{~m}$ depending on the programme). After almost a decade, these precepts were retired [41], while 1989 also brought with it an economic transformation. Free-market construction principles led to a situation in which real estate developers build either singular buildings or complexes of multi-family buildings without a proper service programme. This problem is particularly prevalent in large cities. These dysfunctions have become particularly severe during the COVID-19 pandemic in many cities, Cracow included. Within older housing estates, local service centres continued to satisfy the needs of residents within the radius of pedestrian access. These centres featured both local markets, as well as commercial pavilions, whose siting and layout have turned out to be particularly favourable. Insofar as recent years have seen the building of shopping malls with internal passages, the older commercial pavilions housed small premises accessible from the outside. For safety reasons, shopping galleries were closed by government order, which did not extend to these small stores. The residents of new housing estates that were not equipped with local service centres were forced to travel by car or public transport to other areas of the city. This migration was dangerous for two reasons-due to the use of public transport and due to contacts with residents from other areas of the city. It can therefore be stated that new urban 
structures are largely unprepared for a scenario in which a portion of the city's residents would be placed in isolation.

Concentrations of big-box stores with shopping galleries that form Cracow's subcentres were closed during the epidemic. Thus, the residents of the suburban zones (particularly the municipalities surrounding Cracow, where urban sprawl is particularly pronounced) were forced to satisfy their needs through local, suburban centres, which were overloaded (large queues formed in front of store entrances).

The historical city centre has lost the rank of a city/agglomeration centre in functional terms. Due to its block-based development with services accessible from street level, some premises continued to operate, yet provided services of local significance only. All highertier services and services for tourists were closed. Local markets and stores used by the residents of the city centre continued to operate.

As a summary of the situation during the imposition of the strictest sanitary measures during the spring of 2020 in Cracow, it can be stated that all centres ceased to operate. Only local service centres remained open. The constellation of local, housing estate-level and district-level centres of essential or secondary significance turned out to be a foundation of security. In the historical centre, activities associated with tourism ceased completely, as services associated with entertainment and culture were closed.

The streets became empty and, as a consequence, most premises were closed, while local markets and individual commercial premises continued to provide services to local residents. It can be said that the city centre functioned on the local or supra-local scale because of political reasons and free-market principles (lack of demand).

\section{Results}

Service polycentricism, in the face of the pandemic, took on a new significance because of sanitary requirements. Cracow's polycentricism did not perform successfully under the new conditions of strict sanitary requirements associated with the COVID-19 outbreak. Population concentrations in large service centres face a high risk of infection both at their destination and during the trip. Higher-tier services were largely closed during the threat's peak. Global service operations placed in office centres were distributed due to working remotely from home and virtual space. As large commercial centres were closed, local service centres remained open-particularly those accessible directly from the street or parking lot.

This can be a turning point in architectural design - signifying a return to traditional solutions: stores along a commercial street or commercial pavilions that were widespread in the 1970s and 80s in Poland (local centres, accessible from the outside, instead of galleries with internal passages).

The current threat, as well as the high probability of similar situations happening in the future, will probably lead to changes in behaviour patterns of consumers and service providers in reference to siting. Local service centres that are accessible to pedestrians, due to safety-related considerations, can gain significant popularity. Changes in spatial planning trends can also be expected, although they will probably be smaller in scope and will arrive with some delay. Strategic planning [42] should take into account new risks and, in this case, strengthen multicentering. As illustrated by the history of Cracow's development, planning provisions concerning service centres, when detached from political decisions and finances or when not aligned with free-market trends, continue to exist only on paper. Unfortunately, there are no indications as to the weakening of suburbanisation, as it is a global phenomenon. In addition, the strictest sanitary requirements, with bans on walks included, led to enormous frustration among the part of society residing in multi-family buildings and the desire to own one's own backyard has gained further significance in the context of comfort and safety during social isolation. 
1. Döllner, Jürgen, Konstantin Baumann, and Henrik Buchholz. Virtual 3D city models as foundation of complex urban information spaces. na, (2006).

2. Billen, Roland, et al. "3D City Models and urban information: Current issues and perspectives-European COST Action TU0801." (2014)

3. Moser, J., F. Albrecht, and B. Kosar. "Beyond visualisation-3D GIS analyses for virtual city models." International Archives of the Photogrammetry, Remote Sensing and Spatial Information Sciences 38.4 (2010): W15.

4. Wolff, Markus, and Hartmut Asche. "Geospatial modelling of urban security: A novel approach with virtual 3D city models." International Conference on Computational Science and Its Applications. Springer, Berlin, Heidelberg, 2008.

5. Sinkienè, Jolita, Inga Stankevičè, and Kristina Navickaitè. "Creating safer cities through urban planning and development." Public Policy and Administration 11.3 (2012): 390-403.

6. Ziobro, Anna. "Planning-related factors of the quality of the residential environment in the modelling of the functional spatial structure of Cracow." Czasopismo Techniczne 2018.Volume 2 (2018): 97-108.

7. Karwińska, Anna, Aleksander Böhm, and Michał Kudłacz. "The phenomenon of urban sprawl in modern Poland: Causes, effects and remedies." Zarządzanie Publiczne/Public Governance 3 (45) (2018): 26-43.

8. Kubeš, Jan. "European post-socialist cities and their near hinterland in intra-urban geography literature." Bulletin of Geography. Socio-economic Series 19 (2013): 19-43.

9. Lityński, Piotr, and Artur Hołuj. "Urban sprawl costs: The valuation of households' losses in Poland." Journal of Settlements and Spatial Planning 8.1 (2017): 11-35.

10. Slaev, Aleksandar D., et al. "Suburbanization and sprawl in post-socialist Belgrade and Sofia." European Planning Studies 26.7 (2018): 1389-1412.

11. Schmidt, Stephan, Stefan Fina, and Stefan Siedentop. "Post-socialist sprawl: A cross-country comparison." European Planning Studies 23.7 (2015): 1357-1380] [Lennert, József, et al. "Measuring and predicting long-term land cover changes in the functional urban area of Budapest." Sustainability 12.8 (2020): 3331.

12. Cooke, Philip N., and Luciana Lazzeretti, eds. "Creative cities, cultural clusters and local economic development." Edward Elgar Publishing, 2008.

13. Nowakowski M., „Centrum miasta. Teoria, projekty, realizacje,” Arkady, Warszawa 1990.

14. Lösch A., Gospodarka przestrzenna. Teoria lokalizacji. PWE, Warszawa 1961

15. Hall, Peter Geoffrey, and Kathy Pain, eds. The polycentric metropolis: learning from mega-city regions in Europe. Routledge, 2006.

16. Taylor, Peter J., David M. Evans, and Kathy Pain. "Application of the interlocking network model to mega-city-regions: measuring polycentricity within and beyond city-regions." Regional Studies 42.8 (2008): 1079-1093.

17. Davoudi, Simin. "European briefing: polycentricity in European spatial planning: from an analytical tool to a normative agenda." European planning studies 11.8 (2003): 979-999.

18. Vasanen, Antti. "Spatial integration and functional balance in polycentric urban systems: A multi-scalar approach." Tijdschrift voor economische en sociale geografie 104.4 (2013): 410-425.

19. Christaller, Walter. Die zentralen Orte in Süddeutschland: eine ökonomisch-geographische Untersuchung über die Gesetzmässigkeit der Verbreitung und Entwicklung der Siedlungen mit städtischen Funktionen. University Microfilms, 1933.

20. Berry, Brian JL. "Cities as systems within systems of cities." Papers in regional science 13.1 (1964): 147-163.

21. Castells Manuel, Społeczeństwo sieci, Wydawnictwo Naukowe PWN, Warszawa 2007.

22. Camagni, Roberto P. "From city hierarchy to city network: reflections about an emerging paradigm." Structure and change in the space economy. Springer, Berlin, Heidelberg, 1993. 66-87.

23. Parr, John. "The polycentric urban region: a closer inspection." Regional studies 38.3 (2004): 231-240.

24. Marston, Sallie A., and Neil Smith. "States, scales and households: limits to scale thinking? A response to Brenner." Progress in human geography 25.4 (2001): 615-619.

25. Paddison, Ronan, ed. Handbook of urban studies. Sage, 2000.

26. Leszczycki S., Eberhardt P., Heřman S., Aglomeracje miejsko-przemysłowe w Polsce 1966-2000, Biuletyn, z. 67 KPZK PAN, Warszawa 197.

27. Gontarski Z., Obszary metropolitalne w Polsce. Biuletyn KPZK PAN, z. 109, Warszawa 1980

28. Karbownik W., Jędraszko A., Planowanie aglomeracji miejskich w Polsce. Rozwój aglomeracji warszawskiej - studia i propozycje, PWN Warszawa 1978

29. Markowski T., Marszał T. (red.), Metropolie, obszary metropolitalne: problemy i pojęcia podstawowe, Polska Akademia Nauk, KPZK, Warszawa 2006

30. Smętkowski M., Delimitacja obszarów metropolitalnych w Polsce - nowe spojrzenie, Wydawnictwo Uniwersytetu Ekonomicznego we Wroclawiu 2012

31. Seo, Jong Gook, James E. Moore, and Peter Gordon. "A sequential land use/transportation model with externalities: Linking the dynamics of regional economic growth and urban spatial structure." Transport, Land-Use and the Environment. Springer, Boston, MA, 1996. 383-411.

32. Tissandier, Patrice, Trung Tien Phan Quang, and Daniel Archambault. "Defining polycentric urban areas through commuting cohesion in France." Methods for Multilevel Analysis and Visualisation of Geographical Networks. Springer, Dordrecht, 2013. 189-206. 
33. Heikkila, Eric, et al. "What happened to the CBD-distance gradient?: land values in a policentric city." Environment and planning A 21.2 (1989): 221-232.

34. Ogrodnik, Daniel. "Milan's urban nodes-an example of a polycentric city." Czasopismo Techniczne (2015).

35. Aguilera, Anne, and Dominique Mignot. "Urban sprawl, polycentrism and commuting. A comparison of seven French urban areas." Urban Public Economics Review 1 (2004): 93-113] i wiele innych.

36. Eubank, Stephen, et al. "Modelling disease outbreaks in realistic urban social networks." Nature 429.6988 (2004): 180-184.

37. Wang, $\mathrm{Pu}$, et al. "Understanding the spreading patterns of mobile phone viruses." Science 324.5930 (2009): 1071-1076.

38. Balcan, Duygu, et al. "Seasonal transmission potential and activity peaks of the new influenza A (H1N1): a Monte Carlo likelihood analysis based on human mobility." BMC medicine 7.1 (2009): 45.

39. Roth, Camille, et al. Commuting in a polycentric city. Vol. 1592. No. arXiv: 1001.4915. 2010.

40. Korzeniewski W., Normatyw urbanistyczny i mieszkaniowy - 1974. Informator, z serii: Problematyka budownictwa 139, Centralny Ośrodek Informacji Budownictwa, Warszawa 1980.

41. Dąbrowska-Milewska, Grażyna. "Standardy urbanistyczne dla terenów mieszkaniowych-wybrane zagadnienia." Architecturae et Artibus 2 (2010): 17-31.

42. Albrechts, Louis. "Strategic (spatial) planning reexamined." Environment and Planning B: Planning and design 31.5 (2004): $743-$ 758. 